\title{
Impact of Tariff Structures on FDI in Pakistan
}

\author{
${ }^{1}$ Arslan Pervez, ${ }^{2}$ Qaisar Ali Malik \\ ${ }^{I}$ FUIRC, Department of Business \& Economics. \\ ${ }^{2}$ Assistant Professor, FUIRC, Department of Business \& Economics.
}

\begin{abstract}
The purpose of present study is to construct a relationship between tariff structures and FDI to identify and measure how and to what extent tariff structures of a country influences the FDI in today's era of increased capital mobility. On the basis of the review of literature the study took tariff structure as independent variable to measure its effect on FDI being dependant variable. Gross capital formation, inflation and GDP are taken as control variables affecting FDI in relation to changes in tariff structures. Time series secondary data regarding the studied variables covering the period 1973 - 2011 is taken for conducting the analysis. Data analysis for the present study is conducted through Augmented Dickey Fuller Test (ADF) for data stationarity; Johansen Cointegration Test for data cointegration; and Least Square Regression Analysis for measuring the impact of explanatory variables on dependant variable. The study concludes that lower tariff structures, higher GDP and higher inflation increase the foreign direct investment whereas gross capital formation has no effect on the foreign direct investment. The study recommends that tariff structures should be framed out in a way to provide maximum tax incentives to foreign investors in order to promote FDI into the country. Moreover there is a defiant need of stabilizing the political, social and economic systems as well along with the decreasing of tariff structures to improve the FDI. The study is of crucial significance for a country like Pakistan; to attract more FDI through framing out reasonable tariff structures; for the stability and growth of the economy of the country.
\end{abstract}

Keywords: Tariff Structure, FDI, Gross Capital Formation, Inflation, GDP

\section{Introduction}

Investment for a country is one of the most important components of income and growth and therefore, by many policy makers, it is considered to be indispensible for the stability of the economy. Most of the macroeconomic theories support that increase in savings and investments in an economy lead to the upward growth curve of that economy. Foreign direct investment has been the most important inflow of income and business that an economy attracts and then benefits from it. The literature however does not always supports the relationship between economic growth of a country and foreign direct investment. The empirical studies from the developed part of the world conclude that the relationship between foreign direct investment and economic growth is contradictory and conflicting with no statistically significant relationships found (Vu \& Noy, 2009). Hence the policy makers attempt to manage the tax income of the economy through FDIs. The tariff structures of the economy have a significant influence on the levels of FDI that a country attracts and thus it is important to craft the right combination of tax structure amongst other factors to attract just the right amount of foreign investment into the country. The present study intends to establish a relationship between foreign direct investment and the tariff structures in Pakistan.

\subsection{Significance of Study}

The study is of crucial significance for a country like Pakistan; to attract more FDI through framing out reasonable tariff structures; for the stability and growth of the economy of the country. However the study presumes that the taxes imposed on FDI would be collected as per the tariff structures developed from time to time.

\subsection{Objective of Study}

The basic research objective of the present study is to construct a generalizable relationship between tariff structures and FDI to identify how tariff structures of a country influences the inflow of FDI, in the world of increased capital mobility.

\section{Literature Review}

Kim et al. (2012) stated that the impact of foreign direct investment on economy is still controversial in the present literature as to whether the impact of foreign direct is positive or negative on the promotion of economic growth. However Bekaert \& Harvey (2000) pointed out that there is actually conventional wisdom attached to the increase in foreign direct investment into the country. FDI inflow is important in promoting economic growth because of two important reasons. Firstly, foreign direct investment enable to produce positive 
externalities for the organization in terms of disseminating advanced technological and managerial practices into the country that is receiving foreign investment and secondly, by this inflow into the country, that is foreign direct investment is more resistant to external global changes than other types of inflows into the country. Craig and dollar (1996) observed that FDI accelerates the economic growth of the country and it's contributing in the development of human resource, capital formation, interlinked with global markets and advancement in technology. Moreover they found that FDI and development indicators are linked positively. Mishkin (2009) mentioned that foreign direct investment leads to technological advancement in the host country as well as managerial advancement. This then overall contributes to making the structures of the host country stronger. Varsakelis et al. (2010) stated that the significant reduction in the trade barriers during the last decade and the resulting increase in the liberalization of capital flows have actually made foreign direct investment an extremely important element for the economies. Azemar \& Delios (2007) stated that the variations in FDI against its various studied determinants depend significantly on the level of economic development in the host country.

Girma (2005) revealed that positive absorption capacity of the host country allows the process of positive spillovers of foreign direct investment to speed up, hence ensuring the better use of the foreign direct investment for achieving economic growth. Absorption capacity is determined through a number of factors including the new capital formulation; that is the conversion of savings into investment of a country; and the economic stability. Thus the policy makers must offer some incentives to encourage new capital formulation and economic stability in the country so as to increase the inflow of foreign direct investment. The economic stability is being measured by the inflation rate and the new capital formulation is being measured by the index itself. These two measures mutually denote the absorption capacity of the host country and the economic stability of the country. Tyler (1981) studied middle east countries and found that the growth in the manufactured exports in a country lead to the progress further leading to an increase in the absorptive capacity for further investment. Hence an increase in the trade would lead to improvement in the economy if the absorptive capacity of the country is able enough to do so in the long run (Krueger, 1978). Hansen \& Rand (2005) argued that FDI and gross capital formation are associated in the long run and that FDI has impact on GDP through implementation of technology and transfer of awareness. Wang et al (2004) and Tsen (2006) emphasized on the fact to better understand this relationship, one has to distinguish whether the situation is of a growth led trade or a trade led growth because the phenomena significantly different in their dynamics.

Lim (2007) stated that restructuring of the tariff rates is actually one of the ways through which countries seek to attract foreign direct investment into the country. In this regards there are a number of ways through which FDIs can be attracted towards the country. In this context the economic determinants including the policy structures and the level of business facilitation is of significant importance in aiding to increase foreign direct investment in the country. Varsakelis et al. (2010) stated that there is little doubt about the fact that the accelerated growth of the foreign direct investment in the recent past is a result of the tax differentials that have been used by the policy makers to attract FDI all over the world. Haufler \& Wooton (1998) compared and analyzed the tax structures of two developing countries of different sizes and found that foreign direct investment was more attracted towards the larger countries. The reason for such attraction was the autonomy of prices to be charged by the investor though the tax structures in the larger country were comparatively higher. Basically, smaller sized countries offering smaller tariff rates is basically like a compensation for their otherwise unattractive markets (Raff and Srinivasan, 1997). Hines (2005) suggested that smaller and open economies should comprehensively avoid the taxation of income earned on foreign investment so as to best incentivize the flow of investment into the country. The study concluded that the return that the country earns through increased foreign investment is much more than what it earns through taxing the investors' income. Desai et al (2004) noted that multinational organizations actually adjust their debt levels in accordance with the corporate tax rates that they are faced with. Hence it endorses that the behavior of the multinational organizations is strongly determined by what tax rates they are facing with. Desai et al. (2003) discussed that even though most of the current literature on foreign direct investment focuses on corporate income taxes to analyze the attractiveness and the level of FDI, non income taxes or the indirect taxation is also an important determinant of FDI in the country because it burdens the operations of the organizations investing in a particular country. The literature suggests though high corporate tax rates depress foreign direct investment whereas indirect taxes are not found having strong significant relationship with FDI

Moreover it is also dependent on the phase of development that the country is in i.e. the equilibrium of taxes and foreign investment would be on a different position in the United States of America than that in Pakistan. The implication in this case is that the relationship between the two variables under consideration requires significant probing to actually understand what the dynamics are. Azemar and Delios (2008) criticized strongly that a great deal of the literature has been focused on finding the effect of tax rates on the foreign direct investment in developed countries of the world, whereas the importance of studying this relationship lies in the developing countries. Devereux and Griffith (1998) stated that there is a lack of empirical evidence regarding 
this issue for the developing countries because most often, there is a difficulty in calculating the appropriate tax measures for developing countries. Moreover regarding literature available on foreign direct investment in developing countries, it has to be noted that either researchers have significantly focused their studies on United States of America or in OECD countries (Benassy-Quere et al., 2005) or have not distinguished between low income and high income countries (Mutti \& Grubert, 1991; Hines \& Rice, 1994). Such studies have implicitly assumed that the tax elasticities for foreign direct investment are identical for both the types of countries which in reality is not the case as has been clearly pointed out by Blonigen and Wang (2005). Hence these systematic differences between the high income and low income countries; as far as the tax elasticities are concerned; imply that the data from the two sets cannot be pooled together for a study. Thus the developing countries have to be studied separately (Mutti and Grubert, 2004).

The impact of tariff structure and FDI is rarely investigated in Pakistan. Trade policy of Pakistan has been fluctuating; in 1950s protectionist policies were followed to save the infant industries; since 1960s imports started and exports were given policy boosts through important substitution policies and devaluation of the currency; in 1980s trade was liberalized Balassa (1971) by decreasing the tariff rate from 17 percent to 10 percent in 1987 (Hussain, 2003); the optimal tariff rate was limited to 25 percent which was further reduced to 14.7 percent (Kemal et al. 2002). Resultantly imports had grown significantly leaving the national production and exports to be limited. UNCTAD (2005) showed that foreign direct investment is less in the favor of developing countries (almost by 4.5 times) than in the favor of the developed countries. Apart from the tax structures, the mediators are the weak economies and infrastructures, the political and social risks involved, illiteracy and enforcement of property rights. Pakistan has followed market oriented policies for two decades and getting higher amount of FDI inflow. In Pakistan significance of FDI inflow is highlighted in the form of size and percentage of gross capital formation. Shah \& Ahmad (2003) established that change in GDP and tariff rate carry significant impact on FDI in long run. While tariff rate also support FDI in short run. Aqeel \& Nishat (2004) identified that FDI is attracted through government policies. The variables like corporate tax and custom duties are significant. Awan \& Zaman (2010) stated that FDI and inflation rate are significantly positive to persuade foreign investors. Nonetheless, one thing that has been stated regarding foreign direct investment and tax structure is that it leads to longer run benefits for the host countries. The openness in trade and capital mobility allows the country to reap fruits in the future (Shahbaz, 2012).

\subsection{Measurement of Variables}

\section{Methodology}

Craig and dollar (1996) observed that FDI accelerates the economic growth of the country and contributes to the development of capital formation. Moreover FDI and development indicators are associated positively. Azemar \& Delios (2007) stated that the variations in FDI against its various studied determinants depend significantly on the level of economic development in the host country. Girma (2005) revealed that positive absorption capacity of the host country ensures the better use of the foreign direct investment for achieving economic growth. Absorption capacity is determined through a number of factors including the new capital formulation and the economic stability. The economic stability is being measured by the inflation rate and the new capital formulation is being measured by the index itself. Hansen \& Rand (2005) argued that FDI and gross capital formation are associated in the long run and that FDI has impact on GDP through implementation of technology and transfer of awareness. Lim (2007) stated that restructuring of the tariff rates is actually one of the ways through which countries seek to attract foreign direct investment into the country. In this context the economic determinants including the policy structures and the level of business facilitation is of significant importance in aiding to increase foreign direct investment in the country. The present study addresses the issue; as to what extent the variations in the tariff structures change the foreign direct investment with respect to the development stage of Pakistan. On the basis of the review of literature the study took tariff structure as independent variable to measure its effect on FDI as dependant variable. Gross capital formation, inflation and GDP are taken as control variables affecting FDI in relation to changes in tariff structures.

\subsection{Data Collection}

Time series secondary data regarding the studied variables is used for conducting the analysis and getting the results of the study. Time period of the study is 38 years starting from 1973 to 2011. The reason for selecting the period is that it encompasses the long run variations in the studied variables. The data was collected from online resources of World Bank, IFS and Ministry of Commerce, Pakistan.

\subsection{Predicted Relationship}

On the basis of review of literature and the findings of the earlier such studies, following relationship is expected as shown in the hypothesis shown below:

H1: Higher tariff structure decreases the foreign direct investment. 
H2: Higher GDP increases the foreign direct investment.

H3: Higher inflation increases the foreign direct investment.

H4: Higher gross capital formation increases the foreign direct investment.

For the purpose of data analysis, the above stated relationships can be mathematically expressed as:

$\operatorname{Ln}(\mathrm{FDI})=\beta 0+\mathrm{Ln}(\mathrm{GDP})+\mathrm{Ln}(\mathrm{INF})+\mathrm{Ln}(\mathrm{CAP})+\operatorname{Ln}(\mathrm{DTR})+$ error

Where;

FDI $=$ Foreign Direct Investment in Pakistan

GDP $=$ Real Gross Domestic Product

$\mathrm{CAP}=$ Gross Capital Formation

DTR $=$ Change in Tariff Rate

INF = Inflation Rate

\subsection{Data Analysis}

Data analysis for the present study is conducted through Augmented Dickey Fuller Test (ADF) for data stationarity; Johansen Cointegration Test for long term association of variables; and Regression Analysis for measuring the impact of explanatory variables on dependant variable.

\section{Analysis \& Discussion}

Augmented Dickey Fuller Test (ADF) is used to test the data stationarity. The results in table 4.1 below indicate that all the selected variables including FDI, GDP, INF, CAP and DTR are stationary at first difference with intercept, trend and none.

Table 4.1

Unit Root Test: ADF

Unit Root Conducted at first difference

\begin{tabular}{|l|l|l|l|}
\hline & Intercept & Trend & NONE \\
\hline FDI & -9.04 & -8.9599 & -8.338 \\
\hline GDP & -7.850 & -7.822 & -3.723 \\
\hline INF & -5.36 & -5.371 & -5.47 \\
\hline CAP & -6.087 & -6.271 & -4.05 \\
\hline DTR & -6.777 & -6.864 & -6.9064 \\
\hline
\end{tabular}

After testing for data stationarity data co integration is tested through Akaike Information Criteria (AIC). AIC are lowest at assumption of "no intercept and no trend" represented by "Assumption 1" as in table 4.2 below. This assumption is taken to execute co-integration test.

Table 4.2

Co-integration Assumptions Summary

\begin{tabular}{|l|l|l|l|l|l|}
\hline \multicolumn{7}{|c|}{ Akaike Information Criteria by Model and Rank } \\
\hline & Assumption 1 & Assumption 2 & Assumption 3 & Assumption 4 & Assumption 5 \\
\hline 0 & -2.154341 & -2.154841 & -3.081116 & -3.081116 & -2.958554 \\
\hline 1 & -3.181850 & -3.299749 & -3.887583 & -4.072431 & -3.984435 \\
\hline 2 & -3.537974 & -3.637652 & -3.997227 & -4.128632 & -4.064716 \\
\hline 3 & -3.430834 & -3.690441 & -4.002491 & -4.131353 & -4.054769 \\
\hline 4 & -3.181969 & -3.527465 & -3.710678 & -3.885414 & -3.861964 \\
\hline 5 & -2.669376 & -3.160965 & -3.160965 & -3.523199 & -3.523199 \\
\hline
\end{tabular}

Cointegration test result discloses that Eigen values are greater than critical values therefore livelihood ratio indicates four cointegration equation at 5\% significant level. The trend assumes that there exists no trend in the given time series. The assumption used in the table 4.3 below is "no trend and no intercept".

Table 4.3

Co-integration test

\begin{tabular}{|l|}
\hline Sample: 138 \\
\hline Included observations: 36 \\
\hline Test assumption: No deterministic trend in the data \\
\hline Series: FDI GDP INF CAP DTR \\
\hline Lags interval: 1 to 1 \\
\hline
\end{tabular}




\begin{tabular}{|l|l|l|l|l|}
\hline & Likelihood & 5 Percent & 1 Percent & Hypothesized \\
\hline Eigenvalue & Ratio & Critical Value & Critical Value & No. of CE(s) \\
\hline 0.794655 & 118.5413 & 59.64 & 65.25 & None $* *$ \\
\hline 0.598151 & 61.55093 & 38.98 & 44.85 & At most $1^{* *}$ \\
\hline 0.361361 & 28.73048 & 23.41 & 28.95 & At most $2 *$ \\
\hline 0.264122 & 13.85752 & 13.35 & 15.81 & At most 3* \\
\hline 0.042053 & 1.546668 & 4.48 & 7.65 & At most 4 \\
\hline$*(* *)$ denotes rejection of the hypothesis at 5\%(1\%) significance level \\
\hline
\end{tabular}

Least square regression results in table 4.4 below indicate that GDP, INF and DTR are significant predictors of FDI whereas CAP is insignificant predictor of FDI. The three variables; GDP, INF and CAP are positively associated to FDI whereas DTR is negatively associated to FDI. Adjusted $\mathrm{R}^{2}$ depicted that almost 89 percent of the variability in the foreign direct investment in the country is due to the changes in the explanatory variables. Probability of F statistics indicates the fitness of overall model. The results supported the acceptance of H1 higher tariff structure decreases the foreign direct investment; H2 - higher GDP increases the foreign direct investment; and $\mathrm{H} 3$ - higher inflation increases the foreign direct investment. $\mathrm{H} 4$ - higher gross capital formation increases the foreign direct investment; is rejected being insignificant predictor though the observed relationship is positive as predicted.

Table 4.4

Least Square Estimation

\begin{tabular}{|l|r|r|r|r|}
\hline \multicolumn{5}{|l|}{ Sample(adjusted): 239} \\
\hline Included observations: 38 after adjusting endpoints \\
\hline Variable & \multicolumn{1}{l|}{ Coefficient } & \multicolumn{1}{l|}{ Std. Error } & t-Statistic & \multicolumn{1}{l|}{ Prob. } \\
\hline GDP & 0.901444 & 0.237764 & 3.791335 & 0.0006 \\
\hline INF & 0.714773 & 0.218422 & 3.272449 & 0.0025 \\
\hline CAP & 0.412224 & 0.404538 & 1.019001 & 0.3156 \\
\hline DTR & -1.220749 & 0.605113 & -2.017390 & 0.0518 \\
\hline C & 5.454406 & 7.682404 & 0.709987 & 0.4827 \\
\hline R-squared & 0.897596 & Mean dependent var & 19.17615 \\
\hline Adjusted R-squared & 0.885183 & S.D. dependent var & 1.765124 \\
\hline S.E. of regression & 0.598106 & Akaike info criterion & 1.931981 \\
\hline Sum squared resid & 11.80511 & Schwarz criterion & 2.147453 \\
\hline Log likelihood & -31.70765 & F-statistic & 72.31307 \\
\hline Durbin-Watson stat & 1.689204 & Prob(F-statistic) & 0.000000 \\
\hline
\end{tabular}

\section{Conclusion}

The above analysis and discussion concludes that lower tariff structures, higher GDP and higher inflation increase the foreign direct investment whereas gross capital formation has no effect on the foreign direct investment. Hence tariff structures should be framed out in a way to provide maximum tax incentives to foreign investors in order to promote FDI into the country. Though Pakistan presently needs huge sum of money to handle the present crisis and support the economy; and these funds may be generated, for the time being, through imposing high direct and indirect taxes on foreign investments; but the higher tariff structures would discourage the foreign investment as is obvious from the findings of the study. Moreover the funds generated through higher tariffs may be highly insignificant as against the overall economic benefits that could come into the stream due to the increased FDI over the long run. A careful investigation and analysis is required as to what extent the tariff structures may be increased without adversely affecting the FDI. In case of Pakistan despite of decreasing tariff structures FDI is continuously decreasing because of the present bundles of crisis Pakistan is facing. A cost benefit analysis needs to be conducted to evaluate the benefits of tax incentives to be granted as against the cost of political, social and economic instability the country is facing. Hence there is a defiant need of stabilizing the political, social and economic systems as well along with the decreasing of tariff structures to improve the FDI. 


\section{References}

[1] Aqeel, A. and Nishat, M. (2004), The Determinants of Foreign Direct Investment in Pakistan, The Pakistan Development Review, 43, 651-664.

[2] Azemar, C. and Delios, A. (2007). Tax competition and FDI: The special case of developing countries, Journal of the Japanese and International Economies, Vol. 22 (1), pp. $85-108$

[3] Balassa, B. (1971). The Structure of Protection in Developing Countries, John Hopkins University, Issue 3, pp 309-310

[4] Benassy-Quere et al. (2005). How does FDI react to corporate taxation, International Public Finance, Vol. 12 (5), pp. 583 - 603

[5] Blonigen, B. and Wang, M. (2005). Inappropriate pooling of wealthy and poor countries in empirical FDI studies, Institute for International Economics, Washington, DC (2005), pp. 221-243

[6] Danish Ramzan and Adiqa Kausar Kiani "Analyzing the Relationship between FDI, Trade Openness and Real Output Growth: An ECM Application for Pakistan” International Journal Of Basic And Applied Science, Vol. 01, No. 02 Oct 2012

[7] Desai, M., Foley, F. and Hines, J. (2003). Foreign direct investment in a world of multiple taxes, Journal of Public Economics, Vol. 88 (12) Available through: Science Direct \{Accessed: 26th Nov 2012]

[8] Devereux, M. and Griffith, R. (1998). Taxes and the location of production: Evidence from a panel of us multinationals, Journal of Public Economics, Vol. 68, pp. 335 - 367.

[9] Eicher, T., Helfman, L. and Lenoski, A. (2010). Robust FDI determinants: Bayesian Model Averaging in the presence of selection bias, Journal of Macroeconomics, Vol. 34 (3) pp/ $637-651$

[10] Grubert, H. and Mutti, J. (1991). Taxes, tariffs and transfer pricing in multinational corporate decision making, Economic Statistics, Vol. 73 (2), pp. $283-285$.

[11] Haufler, A. and Wooton, I. (1998). Country size and tax competition for foreign direct investment, Journal of Public Economics, Vol. 71 , pp. $121-139$

[12] Henrik Hansen and John Rand (2005) "Causal Links between FDI and Growth in Developing Countries" Working Papers RP2005/31, World Institute for Development Economic Research (UNU-WIDER).

[13] Hines, J. and Rice, E. (1994). Fiscal paradise: Foreign tax havens and American business, Quarterrly Journal of Economics, Vol. 109 (1), pp. $149-182$

[14] Hussain et al. (2003). Pakistan's exports competitiveness in global market, Key Issues in Pakistan's Economy, State Bank of Pakistan, Karachi

[15] Kemal et al. (2002). Exports and economic growth in South Asia, Pakistan Institute of Development Economics Papers.

[16] Kim, D., Lin, S. and Suen, Y. (2012. Investment, trade openness and foreign direct investment: Social capability matters, International Review of Economics and Finance, Available through: Science Direct [Accessed: 25th Nov 2012]

[17] Krueger, A. (1978). Foreign Trade Regimes and Economic Development: Liberalization Attempts and Consequences, Ballinger, Cambridge. Journal of Development Economics. Volume 6 Issue 3 pp 447-451

[18] Lim, S. (2008). How investment promotion affects attracting foreign direct investment: Analytical argument and empirical analyses, International Business Review, Vol. 17 (1) Available through: Science Direct \{Accessed: 26th Nov 2012]

[19] Mishkin, F. (2007). Globalization and financial development, Journal of Development Economics, Vol. 89 (2) Available through: Science Direct [Accessed: 25th Nov 2012]

[20] Muhammad Zahid Awan, Bakhtiar Khan, Khair uz Zaman(2010) A Nexus between Foreign Direct Investment \& Pakistan's Economy (Co-Integration \& Error Correction Approach) International Research Journal of Finance and Economics Issue 52 (2010)

[21] Mutti, J. and Grubert, H. (2005). Empirical asymmetries in foreign direct investment and taxation, Journal of International Economics, Vol. 62, pp. $337-358$.

[22] Raff, H. and Srinivasan, K. (1997). Tax incentives for import-substituting foreign investment: Does signaling play a role? Journal of Public Econ., Vol. 67, pp. 167-193

[23] Shah, Z. and Ahmed, Q. M. (2003), The Determinants of Foreign Direct Investment in Pakistan: an Empirical Investigation, The Pakistan Development Review, 42, 697-714

[24] Tyler, W. (1981). Growth and exports expansion in developing economies: some empirical evidence Journal of Development Economics, Vol. 9, pp. 121-130

[25] UNCTAD. (2005). World Investment Report 2005: Transnational Corporations and the Internationalization of R\&D, New York and Geneva: United Nations (2005)

[26] Varsakelis, D., Karagianni, S. and Saradaris, A. (2011). Equilibrium conditions in corporate tax competition and Foreign Direct Investment flows, Economic Modelling, Vol. 28 (1), pp. $13-21$

[27] Vu, T. and Noy, I. (2008). Sectoral analysis of foreign direct investment and growth in the developed countries, Institutions and Money, Vol. 19 (2) pp. $402-413$

[28] Zeshan Atique, Mohsin Hasnain Ahmad and Usman Azhar "The Impact of Fdi on Economic Growth under Foreign Trade Regimes: A Case Study of Pakistan", The Pakistan Development Review 43 : 4 Part II (Winter 2004) pp. 707-718 